\title{
Heilna du Plooy
}

\section{Kontemporêre literatuurteorie en die studie en onderrig van die Afrikaanse letterkunde}

\begin{abstract}
The scene of contemporary literary theory is complex and diverse. This article is concerned with the methodological implications of different theoretical approaches especially in the teaching of Afrikaans literature. The development of different literary theories is discussed to indicate the importance and necessity of theoretical training. After putting forward possible ways of using theory in practical teaching, it is suggested that a theoretical framework suited to the scope and diversity of Afrikaans literature should be developed.
\end{abstract}

\section{Inleiding}

In die beplanningstadium van hierdie artikel het ek gedink dat ek 'n enkele en klein bydrae sou kon maak tot die sinvolle en relevante studie van die Afrikaanse letterkunde. My idee was dat ' $n$ mens met 'n positiewe benadering só met die literatuur sou kon omgaan dat sowel die literatuur as die akademiese en teoretiese bestudering van die literatuur daardeur gestimuleer en ontwikkel word. Hierdie positiewe benadering sou onder meer beteken dat aanvaar word dat die literatuur as 'n besondere en onderskeibare en eiesoortige verskynsel bestaan en ook dat die literatuur geskryf in 'n bepaalde taal oor tyd en ruimte heen onmiskenbaar 'n verskeidenheid vertoon. Dat hierdie strewe - selfs as 'n blote strewe - haalbaar sou kon wees, lyk vir my al hoe meer na 'n idealistiese en selfs naïewe droom. Die terrein van die literatuur en van die literatuurstudie is en word steeds meer geproblematiseer en verre sy dit van my - wat vermoë of intensies betref - om hieroor die aller antwoord te spreek. 
U sien dus dat ek myself ondermyn selfs voordat ek begin, maar terwyl ek myself en my gedagtes dekonstruktief vooraf relativeer en/of uitkanselleer, moet $u$ toegee dat ek myself met die aantoon van my gesindheid ideologies (in die wye sin van die woord) plaas as behorend tot daardie groep mense wat hoop dat die literatuur en die literatuurstudie sinvol en relevant kan wees op 'n verskeidenheid van maniere.

\section{Vertrekpunte}

Vir die doel van hierdie referaat aanvaar ek dus

- dat daar tekste is wat onderskei kan word as literêre tekste;1

- dat teorieë oor die literatuur en die literatuurstudie bestaan en teenswoordig 'n belangrike rol speel in gesprekke oor die literatuur en die literatuurstudie; 2

- dat die argumentasie hier primêr om die onderrig van Afrikaans as eerste taal gaan.

Ek gee aandag aan die probleme rondom teoretiese benaderings in die onderrig en laat ander probleme daar.

\section{Probleemstelling}

Die probleem waaraan ek in besonder aandag wil gee, het te make met die groot hoeveelheid en die uiteenlopende aard van die teorieë wat tans in die literatuurstudie gebruik word. Nie net is die groot verskeidenheid teorie soms verwarrend nie, maar die teorieë sluit mekaar dikwels uit en val mekaar gedurig aan. Vir die dosent wat nie in teorie spesialiseer nie, is dit sekerlik soms moeilik om te besluit watter teorie gebruik moet word en op grond waarvan die besluit vir of teen 'n sekere benadering geneem word. Daar is die vraag of die resultate verkry met een benadering in 'n ander betoog wat volgens ' $n$ ander benadering gevoer word, geïnkorporeer kan word. Hoe moet studente ouer bronne hanteer? Die gevaar bestaan sekerlik dat 'n mens op 'n onaanvaarbare manier eklekties te werk kan gaan. In hoe 'n mate die benadering (teorie) en die filosofiese teelaarde waaruit dit groei, geskei kan word, is 'n meer gekompliseerde vraag, wat desnieteenstaande relevant is.

1. Die omskrywing of definiëring van die objek van die literatuurstudie is 'n epistemologiese kwessie wat tans die moontlikheid al dan nie, die wenslikheid al dan nie, die noodsaak al dan nie van sodanige omskrywing en definiëring aanspreek. Felperin (1985:16) beskou 'n adekwate verantwoording ten opsigte van die objek van die literatuurstudie as noodsaaklik, wat impliseer dat linguistiese en estetiese kwessies onderskei word, maar nie geskei word van sosiale en historiese kwessies nie. Vergelyk ook Jefferson \& Robey (1983:7).

2. Fokkema \& Kunne-Ibsch (1978:1 en 9) stel teoretiese begronding as 'n vereiste vir enige vorm van wetenskaplike literatuurstudie. Alle interpretasie is sekerlik nie slegs van teorie afhanklik nie, maar dat die teoretiese komponent in akademiese aktiwiteite rondom die literatuur onvermydelik is, moet 'n mens toegee. 
Hierdie probleme kan op verskillende maniere aangespreek word. Die twee uiterstes sou die volgende kon wees:

'n Mens kan teoreties totaal selfbewus raak en jouself deurlopend probeer verantwoord in wat jy doen. Deur eksplisiet aan te dui waarmee jy teoreties gesproke besig is, kan jy probeer om jouself te dek teen kritiek wat uit 'n ander teoretiese benadering voortvloei. Dit is egter baie moeilik (onmoontlik!) om presies uit te spel wat 'n mens doen. Trouens, ek weet nie of enige leser, hoe geskool ook al, self presies weet wat alles in 'n bepaalde lesing van 'n teks 'n rol speel nie. Vanweë sy teoretiese, filosofiese en metodologiese agtergrond en verskillende aspekte van die konteks waarin hy lewe en lees, is elke mens 'n onontwarbare samestelling van soveel invloede dat hy beslis nie op 'n bevredigende manier duidelik en definitief kan aandui waarop elke uitspraak in sy lesing berus nie. Heelwaarskynlik sal so 'n leser in die labirint van sy eie sielkundige en akademiese en sosiale samestelling verdwaal lank voordat hy iets van belang oor die teks sou kon sê.

Die ander uiterste is om gewoon maar te lees en verslag te doen oor wat jy gelees het. So sal 'n dosent se taak daarin lê om sy eie lesing aan sy studente voor te hou. Twee sake wat egter hier in gedagte gehou moet word, is die volgende:

Oscar Wilde het gesê: "Criticism is the most civilized form of autobiography", en dit is sekerlik waar. Dit impliseer onder meer dat die literêre en filosofiese en akademiese geskooldheid (of die gebrek daaraan) uit die lesing sal spreek. Daar is sekerlik mense wat buitengewoon begaafd is en sonder skoling kan regkom. Maar, beskik almal oor dié singuliere gawes(!) om so te werk te gaan? Waarskynlik sal selfs 'n singulier begaafde persoon se werk deur teoretiese skoling verryk word deurdat sy werk so meer verskeidenheid en groter aktualiteit sal kan verkry.

In die tweede plek impliseer akademiese en wetenskaplike aktiwiteit dat 'n mens nie maar intuitief ' $n$ bepaalde aktiwiteit beoefen nie, maar dat jy juis en bewustelik die aktiwiteit self ook beskryf en analiseer sodat die metodologiese en inhoudelike winste daarvan beskikbaar kom vir ander beoefenaars van die vak of wetenskap (Jefferson \& Robey, 1983:1-5). Die intuitiewe omgaan met die objek van die studie sal sekerlik by nadere beskouing reeds 'n groot lading teorie vertoon waarvan die gebruiker nie eers self bewus is nie. Trouens, ek dink dit is haas onmoontlik om tans met literatuurstudie besig te wees en op 'n totale teoretiese onkunde of neutraliteit aanspraak te maak. Die minder ingeligde persoon weet net nie wat die teoretiese implikasies is van wat hy doen nie. ${ }^{3}$

3. "The economist J.M. Keynes once remarked that those economists who disliked theory, or claimed to get along better without it, were simply in the grip of an older theory. This is also true of literary students and critics" (Eagleton, 1983:1). 


\section{Die ontwikkeling van die kontemporêre teorie}

In die literatuurstudie (soos in ander dissiplines) kom sekere kernvrae altyd weer na vore: wat is literatuur? Wat is die verhouding tussen literatuur en werklikheid? Wat is die verhouding tussen taal en literatuur? Hoe sien die teorie/kritiek oor die literatuur daar uit en watter terminologie word gebruik? Wat is die verhouding tussen literatuur en teorie? Hierdie vrae word nog steeds gevra en beantwoord, hoewel die antwoorde soms negatiewe antwoorde is.

Tradisioneel was daar oor hierdie vrae min probleme: vanaf Aristoteles tot by die intrinsieke benaderings van die twintigste eeu is daar aanvaar dat daar iets soos literatuur is, dat daar 'n outeur is wat literatuur maak, dat daar 'n literêre kanon is wat vasgestel word op grond van die kwaliteit van tekste en dat daar kritici of teoretici of literatore is wie se taak dit is om die literatuur te verklaar en te bespreek en te evalueer. Daar was vanselfsprekend aksentverskille en -verskuiwings met verloop van tyd, maar oorsigtelik beskou, het dit geen groot probleme vir die onderrig van die literatuur opgelewer nie.

Die ontwikkeling van literêre teorie in die twintigste eeu het egter meegebring dat hierdie kernvrae en die antwoorde daarop wel probleme skep. Die ideaal van wetenskaplikheid wat die Russiese Formaliste nagestreef het, het onvermydelik daartoe gelei dat adekwate antwoorde verskaf moes word op die vrae hierbo genoem. Die daaropvolgende teorieë het voortgegaan om sulke antwoorde te formuleer, en uiteindelik het daar in die twintigste eeu geweldige ontwikkelinge op die terrein van die literêre teorie plaasgevind.

Daar is ' $n$ duidelike patroon van aksie en reaksie op te merk in die ontwikkeling van literêre teorie in die twintigste eeu. Die intrinsieke benaderings (die Russiese Formalisme, die Anglo-Amerikaanse New Criticism en die Duitse werkimmanente Methode) was reaksies op die positivisme en die geistesgeschichtliche metode. In hierdie intrinsieke benaderings is die uniekheid van bepaalde tekste verabsoluteer. Die strukturalisme en semiotiek gee hierteenoor weer meer aandag aan die universele kenmerke van bepaalde literêre soorte. Die Marxistiese benadering en die literatuursosiologie dring weer aan op die kontekstualisering en historisering van die literatuur; 'n noodwendige reaksie op die isolasie van die teks in formalistiese benaderings. Die dekonstruksie wil die finale antwoord gee deur die literatuur en die leser in die oneindige spel van signifikasie op te los en so word kreatiwiteit teoretiese vertrekpunt en eindpunt.

Hierdie proses van aksie en reaksie sal waarskynlik voortduur vir solank as wat mense taal gebruik en vir solank as wat tekste in taal deur mense bestudeer word. Die literêre teorie of literatuurwetenskap moet dus gesien 
word as 'n ontwikkelende en dinamiese dissipline, en die korpus begrippe en terme en metodes sal (soos in die verlede) steeds verander en uitbrei. ${ }^{4}$

Die ontwikkeling van teorie word onder meer gestimuleer en noodsaaklik gemaak deur die ontwikkeling van die literatuur self. ${ }^{5}$ Tans kry ons selfs die situasie dat teorie die tekste stimuleer. Die feit bly egter staan dat hierdie veranderende korpus van literêre tekste bestudeer en beskryf word en daarvoor is woorde nodig. Teorie bestaan dus onder meer om gemeenskaplike terme en begrippe te vind sodat kollegas en studente in die vakgebied mekaar kan verstaan. Leslie Fiedler het in 1950 al gesê: "Literary criticism. . . is always becoming 'something else' for the simple reason that literature is always becoming something else" (Culler, 1987:169).

Die onmoontlikheid van enkelvoudige betekenis is byvoorbeeld nie iets wat teoreties van buite op tekste afgedwing word nie. Modernistiese en postmodernistiese tekste problematiseer self enkelvoudige betekenis deur die aandag te vestig op die gebrek aan referensialiteit en die relatiwiteit van betekenis (Levin, 1977; Hutcheon, 1983). Trouens, reeds Shakespeare se gebruik van woordspelings skep ruimte vir die opheffing van een enkele betekenis. Howard Felperin (1985: hoofstuk 5) beweer selfs dat die Sonnets tyd en ruimte oorleef het, juis as gevolg van hierdie doelbewuste relativering wat steeds nuwe lesings genereer en ontlok. In $A$ Defence of Poetry sê Shelley van 'n goeie gedig die volgende: "And after one person and one age has exhausted its divine effluence which their peculiar relations enable them to share, another and yet another succeeds, and new relations are ever developed, the source of an unforeseen and an unconceived delight" (Elsbree, 1982:6).

In die loop van die afgelope drie dekades het 'n situasie ontwikkel waar die klem geweldig sterk op die teorie begin val het. Die gemoedelike empirisisme waarmee gewerk is, is vervang met teorie wat filosofies veeleisend en wetenskaplik streng is (Felperin, 1985:26-27). Die strukturalisme is verfyn totdat hierdie teorie nie meer net gebruik kon word om tekste te beskryf nie, maar ook om te sê hoe bepaalde soorte tekste struktureel daar sal (en moet?) uitsien. Daar word so 'n gespesialiseerde studie van die menslike tekenstelsels gemaak dat die liefhebber van die literatuur verslae staan oor die kompleksiteit van die stelsels wat hy (oënskynlik sonder veel moeite) hanteer. Die dekonstruksie verwerp die rigiditeit, die reduksionisme en die verabsolutering van die metodologie van die strukturalisme, maar is eintlik net so gesteld op die teoretiese besinning ten grondslag van wat hulle doen. Dekonstruksie

4. Vergelyk Abrams (1953: hoofstuk 1). Wanneer so 'n lang tydperk in oënskou geneem word, kan 'n mens die heen en weer beweeg soos die swaai van 'n pendulum in die wisseling van benaderinge opmerk.

5. Die ontwikkelinge in die literatuur self is nie die enigste faktore wat die vorming en ontwikkeling van teorie beïnvloed nie. Wetenskaplike en sosiale verskynsels kan ongetwyfeld ook in verband gebring word met die ontwikkeling van literêre teorie: dink maar aan Freud in die sielkunde en Marx in die sosiale en politieke wetenskappe (Fokkema \& Kunne-Ibsch, 1978:1-2). 
is so sterk filosofies bepaal dat dié benadering sekere epistemologiese konsekwensies meebring waaraan nie ontkom kan word nie.

In 'n sekere $\sin$ is dekonstruksie die noodwendige uitvloeisel van die ontwikkeling wat in die literatuur self plaasvind. Dekonstruksie doen in 'n groot mate wat die literatuur nog altyd gedoen het: dit gaan om die alternatiewe wyse waarop daar na 'n saak gekyk kan word; dit gaan om die momentele ervaring, om die skryfhandeling en leeshandeling self, Literêre kunsgrepe soos die pun en ambiquity is so oud soos die literatuur self, met Shakespeare se werk as 'n vroeë hoogtepunt. Een van die eienskappe van die literatuur is ook dat dit dikwels gaan om 'n nuwe vervreemde kyk op sake, 'n ondermynende visie wat die bestaande en bekende en geoutomatiseerde siening van sake bevraagteken of omverwerp. Dit is nie net Barthes se lesing van Sarrazine wat sekere opposisies problematiseer nie; die verhaal van Balzac stel self reeds die ontoereikendheid en die verkleurmannetjie-agtige aard van die onderskeidinge aan die orde. ${ }^{6}$ In die nagaan van dekonstruktiewe lesings van tekste val dit ook op dat daar telkens sogenaamde Derridiaanse temas uitgewys word in tekste. ${ }^{7}$ Soos die dekonstruksie nou te werk gaan, het modernistiese tekste al aan die begin van hierdie eeu die outeur ondermyn ten bate van die syn, die presentasie van die teks as teks. Die eerlike dekonstruksionis moet dus toegee dat hy selfs in ouer tekste dikwels 'n onmiskenbare "voorkennis van teorie" vind.8 (Dit geld in elk geval vir die meeste teorie.) In dekonstruksie het die literatuur en literêre teorie egter die naaste aan mekaar gekom wat dit ooit in die geskiedenis was. Daarom dat die dekonstruksie vir die teoretiese teks dieselfde status opeis as vir die literêre teks self.

In die debat wat tans die toneel oorheers, staan dekonstruksie en ideologiekritiek prominent. Ander belangrike teorieë is daar wel, byvoorbeeld die resepsie-estetika, die taalhandelingsteorie, die sogenaamde ESL (Empirical Science of Literature van Siegfried Schmidt van Poetics) terwyl die semiotiesstrukturalistiese benadering nog algemeen gebruik word. Hierdie ander teorieë gryp egter tans nie die verbeelding so sterk aan soos dekonstruksie en ideologiekritiek nie.

By die dekonstruksie moet 'n mens onderskei tussen die tekstueelgerigte dekonstruksioniste (Barthes, Derrida en die Yale-kritici, Miller, Bloom, De Man en Hartmann) en die kontekstueel-gerigte teoretici soos Foucault. Die

6. " ... we could perhaps conclude that ... the literary text conveys a difference from itself which it 'knows' but cannot say, while the critical text in attempting to say the difference reduces it to identity. .." (Johnson, 1980:12).

7. Vergelyk Viljoen (1985:62), Scholtz (1985:66) en Hambidge (1986:76).

8. Felperin (1985:147-199) se dekonstruktiewe lesing van Shakespeare se Sonnets illustreer hierdie stelling. Die voorliefde van die dekonstruksioniste vir die werk van Mallarmé, Lautreamont en Poe kan ook dármee te make hê dat hierdie tekste die dekonstruktiewe manier van dink antisipeer en daarmee in lyn lê.

Frank Rumboll (1985:49) beweer: "Derrida's dialectic of denial and deferral appears, however, to have been prologized in literature, notably by Byron." 
situasie word verder gekompliseer deurdat die Marxistiese kritiek 'n gedaanteverwisseling ondergaan het. Die vroeëre klem op konteks en pragmatiese eise word getransformeer deur die materialistiese basis van Derridiaanse teorie as vertrekpunt te neem. ${ }^{9}$ Post-Althusseriaanse Marxisme beskou die literêre teks as ' $n$ indirekte en elliptiese produk (ekspressie) van ideologie, d.i. die groepsubjektiwiteit en kollektiewe selfbedrog wat verduidelik kan word (nie geïnterpreteer nie) deur referensie na 'n sosiale en historiese ideologie waaroor die teks swyg, maar waardeur die teks geproduseer word. ${ }^{10}$ Vir die Marxistiese kritiek is tekstuele dekonstruksie 'n elitistiese denkwyse wat gedoem is omdat hulle standpunte en stellinginname deur hulle eie redenasie ondergrawe word. Die Neo-marxisme gebruik egter die tekstuele vryheid deur die dekonstruksie verwerf om agter die teks te lees, om dit wat afwesig is in die teks aan die orde te stel in 'n sosiaal en histories bepaalde konteks.

Die tekstueel-gerigte dekonstruksioniste kan hierdie benadering nie aanvaar nie, want volgens hulle is die historiese teks ook 'n taalteks en dan is die literatuur en die geskiedenis aan dieselfde onvermoë tot referensialiteit onderworpe. Vir hierdie dekonstruksioniste is alle taaldiskoerse geslote in taal en dan is die geskiedenis ook 'n mite wat deur mediasie tot stand gebring is. Dit is vir hulle onmoontlik om toegang tot die geskiedenis te probeer vind deur taal omdat taal (geskiedenis sowel as literatuur) net 'n tekstuele manier van bestaan is.

9. Liebenberg (1985) beweer dat die materialistiese basis van Derrida se dekonstruksie in Suid-Afrika en Amerika verlore raak. Hy grond sy siening op Althusser se lesing van die Derridiaanse geskrifte. Althusser beweer dat Derrida nie net die dialektiek wil omkeer nie, maar dit juis wil transformeer soos wat Marx die Hegeliaanse model van die gemeenskap nie net wou omkeer nie, maar grondliggend wou transformeer: "This article of Althusser not only makes clear what is involved when Derrida talks of deconstruction, but also shows a certain allegiance. Although his (Derrida's H. du P.) exact relation to Marx and Lenin remains a big question (cf. an interview with him by Houdebine and Scarpetta in Positions (Derrida, 1981)), he makes it quite clear that what he writes 'can be considered' 'materialist' (ibid.:64) and that his deconstruction is the deconstruction of idealism - the ideology of Hegel". Die vraag bly egter of dit die enigste of die "regte" manier is om Derrida te lees. Meer nog, wie kan oordeel oor dekonstruktiewe lesings van dekonstruksie? Liebenberg (1985:41) gee self die volgende aanhaling uit Of grammatology: “. . . above all the work of deconstruction, its 'style', remain(s) by nature exposed to misunderstanding and nonrecognition".

Liebenberg (1985:44) beskryf ook die Tel Quel-groep se teorie van die teks, wat stel dat betekenis slegs moontlik is op grond van ' $n$ bepaalde stel ideologiese konvensies. Die geskiedenis en die sosiale konteks is egter vir die dekonstruktiewe denke ook 'n teks wat deur mediasie tot stand kom en as sodanig onkontroleerbaar en problematies is, (vgl. die lesing van prof. Johan Degenaar op dic ALV-kongres, September 1988).

10. "Always historisize! This slogan (is) the one absolute and we may even say 'transhistorical' imperative of all dialectic thought... But, as the traditional dialectic teaches us, the historisizing operation can follow two distinct paths, which only ultimately meet in the same place: the path of the object and the path of the subject, the historical origins of the things themselves and that more intangible historicity of the concepts and categories by which we attempt to understand those things" (Jameson, 1981:9). 


\section{Die belang en bydrae van teorie}

Uit die bestudering van die ontwikkeling van die literêre teorie kan die afleiding gemaak word dat teorieë nie op waarheid of universele of ewige geldigheid aanspraak kan maak nie. 'n Teorie is en bly immers 'n teorie. Die literatuur kan ook nie aanspraak maak op waarheid nie en kan daarom ook nie regtig as afdoende bewysplaas vir een of ander verbygegane "waarheid" beskou word nie.

Daar moet egter toegegee word dat die verskillende teorieë werklike probleme en leemtes in mekaar se standpunte en werkwyses aantoon. So kon daar in hierdie eeu groot ontwikkeling in die literatuurwetenskap plaasvind; daar kon wegbeweeg word van die elitistiese geheimsinnige intuïsie van die New Criticism, van die meganisme van die Russiese Formalisme, van die reduksie en die verabsolutering van die metodologie van die strukturalisme. Tans is die beperkinge sowel as die winste van die ideologiekritiek en die dekonstruksie op die agenda.

Daar is dikwels intense onvrede met die moontlikhede wat selfs hierdie verskeidenheid teorie bied. Vir 'n sinvolle gesprek oor die literatuur is dit egter belangrik dat daar 'n redelike mate van konsensus bestaan oor wat onder sekere begrippe en terme verstaan word. Sonder teoretiese begronding van lesings kan die akademiese bestudering van die literatuur nie ontwikkel nie (Fokkema \& Kunne-Ibsch, 1978:9; Jefferson \& Robey, 1983:15).

Miskien is een van die fasette van die probleem in die Suid-Afrikaanse konteks dat wanneer daar te sterk en uitsluitend vanuit die teorie na die literatuur beweeg word, een teorie nie al die vorme en verskynsels in die literêre spektrum kan akkommodeer nie. Een moontlike rede daarvoor is dat die meeste teorie uit Europese bodem groei en na Amerika oorgeplant word, terwyl die tekste in Afrikaans (net soos tekste in ander Afrikatale) van Afrika is. Die omstandighede waarin en waaruit die literatuur hier groei, verskil ingrypend van die teelaarde waaruit hierdie teorieë kom. Die Europese teorie is in baie opsigte 'n organiese voortvloeisel uit die literêre en sosio-politieke ontwikkelinge van die afgelope paar eeue in Europa.

Die vraag wat nou gevra kan word, is: het die totale relativisme van dekonstruksie byvoorbeeld soveel te sê vir die betrokke werk wat die kontemporêre problematiek in hierdie land aanspreek as vir die werk van Mallarmé, Lautreamont en Poe? ${ }^{11}$ En aan die ander kant, vanwaar kry die ideologiekritiek die gesag om een bepaalde ideologie af te dwing op die literatuur en eintlik indirek die geldigheid en relevansie van liriese of individualistiese werk te bevraagteken? Net die gesag wat hulle vir hulself opeis, en ek (en ek is seker ook baie ander akademici wat die literatuur wil

11. Die versoenbaarheid van dekonstruksie met byvoorbeeld die werk van Mallarme is tog duidelik groter as tussen dekonstruksie en die betrokke werk van swart skrywers in Afrikaans. 
bestudeer) bevraagteken die "reg tot gesag" van enige teorie op die terrein van die literatuurstudie. Dit gaan hoogstens om die keuse van 'n benadering en hierdie keuse is nie afdwingbaar nie. ${ }^{12}$

Daar is in verskillende teoretiese benaderinge wonderlike studies oor die literatuur gedoen - in die tradisie van die New Criticism, en ook in die tradisie van die Russiese Formalisme. Jakobson se teksanalises bly modelle van voortreflike werk en Barthes se $S / Z$ staan onbetwis as die standaardwerk van dekonstruktiewe, skryfmatige lees. So kan baie ander voorbeelde genoem word.

Dus, goeie lesers bly goeie lesers afgesien van die teoretiese raamwerk wat hulle aanhang. Dit impliseer dat die teorie alleen nie altyd al die antwoorde op probleme kan verskaf nie. Teorie op sigself maak ook nie noodwendig goeie lesers nie.

Nogtans speel al hierdie faktore 'n rol in die vrugbare studie en onderrig van die literatuur.

\section{Moontlike oplossings}

Howard Felperin bespreek in sy boek Beyond deconstruction (1985) verskillende moontlikhede wat gevolg kan word in die verdere ontwikkeling van die literatuurstudie. Daar kan teruggekeer word na die liberaal-humanistiese tradisie deur die oë en die ore te sluit vir die kritiek daarop en slegs die winste daarvan raak te sien. Daar kan gepoog word om dekonstruksie te institusionaliseer. 'n Derde moontlikheid is dat 'n mens kan historiseer en kontekstualiseer soos wat die ideologiekritiek wil hê dit gedoen moet word.

Volgens Felperin is dit juis hierdie drie moontlikhede wat nie gevolg kan word nie.

1. In die eerste plek kan 'n mens nie vashou aan die konsep van uniforme en ewige betekenis nie (om nie van enkelvoudige betekenis te praat nie!). Die literatuur is geen vorm van evangelie nie en laat hierdie soort benadering uit sigself nie toe nie.

2. Die dekonstruktiewe benadering bied meer moontlikhede en bring veral die wins van kreatiewe lees. In 'n baie interessante en verstommend humanistiese artikel voer J. Hillis Miller (1987) aan dat dit in die lees en onderrig van die literatuur ten diepste om etiese kwessies gaan.

12. Interessant genoeg werk die post-Althusserriaanse ideologiekritiek verkieslik met niebetrokke tekste (vgl. Klopper, 1985:77; vgl. ook Liebenberg (1988) se lesing oor Van Wyk Louw). 'n Mens sou kon sê dat literariteit as bepalende eienskap van die literatuur bloot vervang is met politikaliteit. Word daar in hierdie benadering hoegenaamd aandag gegee of waarde geheg aan verwoorde ideologie of werk hulle uitsluitend met versweë ideologie? Wanneer is verwoorde ideologie aanvaarbaar en op grond waarvan word besluit of 'n teks se verwoorde of versweë ideologie geanaliseer of gebruik word? 
Hy begin sy betoog deur aan te haal uit 'n gedig wat soos volg begin: I must tell you. .."13

- Dit gaan vir hom oor die vraag waarom een mens vir 'n ander iets wil vertel. Waarom kom menslike ervaring in literêre vorm tot uiting en waarom wil een mens sy literêre ervaring met 'n ander deel? Net soos die skrywer aanvanklik uitreik na ander om te kommunikeer en ervaring te deel, so wil die dosent ook sy ervaring van lees met sy studente deel. Meer nog, hy het die verpligting om dit met sy studente te deel.

- Miller aanvaar dat in die lees en deel van literatuur, 'n stel beginsels oor die konsep van die rol van die literatuur op alle vlakke ter sprake kom. Onderrig van die literatuur is ' $n$ etiese kwessie waarby dinge soos die aard van die onderrig, die keuse van studiemateriaal en die keuse van metodologie verantwoord moet word.

- Hy wil die verhouding tot die etiese, die gemeenskap en die geskiedenis betrek in sy keuse en aanbieding van 'n kursus in die literatuurstudie, maar wil steeds die taalgesentreerde leesmetode vooropstel. Hy verduidelik sy benadering deur aan te dui dat hy dekonstruktief wil werk deur die bevraagtekening van die gesag van die outeur, periodiseringskonsepte, enkelvoudige betekenis en die referensialiteit van taal. $\mathrm{Hy}$ aanvaar dat taal geheel en al figuurlik is en stel voor dat daar op die retoriek gekonsentreer word.

Hy plaas dus die teks binne die spektrum van die kultuur as 'n wyer raamwerk, maar wil teksgesentreerd bly werk, en hy gee die volgende riglyne:

- Die primêre etiese verpligting van die dosent is teenoor die literêre teks. Die teks moet gelees word en aangebied word soos wat dit is. Die leser kan nie willekeurig lees nie en die teorie kan nie die leesproses finaal bepaal nie. Daar moet egter met 'n oop oog en 'n oop gemoed gelees word sodat die nuwe en die vreemde in die teks raakgesien kan word.

- 'n Lesing moet reg laat geskied aan die taalmatige aard van die teks en die studie in die algemeen.

- Hy staan 'n vergelykende benadering voor.

Hoewel 'n mens hierdie benadering baie goed sal kan gebruik, gee dit nog geen antwoord op die eintlike probleem van dekonstruksie as 'n akademiese benaderingswyse nie. Soos wat dekonstruksie filosofies verantwoord word (en die klem op die filosofiese onderbou is so groot dat dit werklik nie veronagsaam kan word nie), kan dit nie binne die huidige institusionele raamwerke geakkommodeer word sonder om in mindere of meerdere mate iets van die benadering prys te gee nie. ${ }^{14}$ Indien hulle getrou bly aan

13. Die gedig waarna Miller verwys is "Young Sycamore" van William Carlos Williams uit Collected Poems (1934).

14. In Framing the sign (1988) gee Jonathan Culler aandag aan die institusionalisering van dekonstruksie. 
wat hulle wil wees en alles abstraheer en relativeer en dekonstrueer sodat uiteindelik die momentele ervaring van die individu soos 'n verskietende ster die enigste gegewe is waarmee gewerk word, sal hulle kontak verloor met die instellings wat die raamwerk verskaf waarbinne die benadering beoefen kan word. As niks kontroleerbaar is nie, as die ganse werklikheid 'n groot teks is, as die enkele moment van wispelturige menslike ervaring die enigste min of meer bepaalbare gegewe van die ganse bestaan is, as enige metafisiese bespiegeling irrelevant is, word akademiese opleiding 'n groot probleem. 'n Mens sou studente moes laat slaag op grond van hulle vermoë om woordspelings te hanteer en om sonder verwysings te skryf (Felperin, 1985:138). Kan kreatiwiteit en oorspronklikheid op 'n regverdige basis beoordeel word? Indien "kennis" weer vereis word, sou dekonstruksie dus nie meer so dekonstruktief kon wees soos wat ons (en die Amerikaners) gedink het dit is nie. Indien dekonstruksie in sy oorspronklike vorm (soos die Amerikaners Barthes en Derrida lees) gebruik word, is daar die gevaar dat in estetisering en teoretisering opgegaan kan word terwyl die band met die gemeenskap deurgesny word. Op die manier kan die nut en relevansie van die literatuurstudie totaal getrivialiseer en gemarginaliseer word.

3. Historisering is volgens Felperin ook nie die antwoord nie. Hoewel die noodsaaklikheid daarvan om die literatuur weer in konteks te plaas nie ontken kan word nie, moet 'n mens daarvan kennis neem dat die ideologiese benadering in sy huidige vorm, die sentrale vraagstukke van die literatuur systap. Hulle analise van die tekortkominge van die ander benaderings is wel in die kol, maar hulle oplossings is nie oplossings nie. Felperin (1985:220) illustreer hoedat die "pseudo-wetenskaplike" manier waarop Althusser en Foucault betekenis vooraf wil bepaal en voorwaardes vir betekenis wil vaslê, deur die taalvaardige dekonstruksioniste sonder veel inspanning gedekonstrueer kan word.

Indien 'n mens in 'n sosio-politiese betoog so met die literatuur wil omgaan, gaan niemand jou seker keer nie, maar vir baie literatuurwetenskaplikes is so 'n werkwyse reduksionisties en onkontroleerbaar willekeurig. Die studie van literatuur as sodanig is binne so 'n benadering 'n luukse, 'n onnodigheid, want hier word die literatuur 'n middel tot 'n doel en slegs die literatuur wat die doel dien, is uiteindelik relevant.

Felperin (1985:220) vat sy bevindinge soos volg saam:

"If deconstruction can be historisized or contextualized, so can any historical context be deconstructed, according to the former has always already deconstructed itself. One system or anti-system can always critique another, because each begins from different premisses, premisses that remain themselves ultimately groundless, a leap of faith without foothold in an a priori truth.

"In so far as the contextual critique of deconstruction is a theoretical one, it is itself deconstructable - of making theories there is, as we are coming to see, 
no end - and in so far as it is a practical or textual one, it operates at a serious disadvantage in relation to the more sophisticated textual practices of the deconstructionists themselves. Moreover, to remain within theory is to allow deconstruction to carry the day by default. For deconstruction, as the only poststructuralist definition and defence of literature on offer, is also the only textual practice attempting to specify and engage the 'literariness', as distinct from the historicity, of our canonical literature, albeit in a way so uncanny and perverse as to shake to its metaphorical foundations the traditional institution of its study" (Felperin, 1985:220).

Dit het tot hiertoe helaas net gegaan oor probleme en tekortkominge: alles wat gesê is, is metterdaad weer ondermyn.

Vir die studie van die Afrikaanse literatuur is daar tog ander moontlikhede, nie nuwes nie, net aangepastes. ${ }^{15}$

Ek dink nie 'n mens soek na 'n teoretiese monisme nie, Net so min as wat eenvormigheid in die literatuur self moontlik is of wenslik is, net so min kan die teorie oor die literatuur eenvormig wees of vir 'n lang tyd dieselfde aanskyn behou.

T.S. Eliot kan hier aangehaal word: "About anyone so great as Shakespeare, it is probable that we can never be right; and if we can never be right, it is better that we should from time to time change our way of being wrong".

As literatuurstudie en -onderrig op die breë kulturele terrein sinvol wil wees, kan ons nie werk met 'n statiese konsep van wat kultuur is nie. As 'n mens dit sou kon regkry om kultuur as 'n dinamiese en voortdurend ontwikkelende proses te sien, 'n proses wat per definisie sonder program en onbewysbaar, maar tog onderskeibaar is, gaan dit miskien makliker wees. Dan kan 'n mens ook na die literatuur en die literêre teorie kyk soos dit voortdurend dinamies ontwikkel en verander: uit besinning oor voorafgaande en bestaande dinge word geleer, terwyl nuwe aanpassings steeds gemaak word.

Op hierdie manier kan 'n mens selfs konsepte soos outeurskap en die kanon behou, met die kwalifikasie dat die outeur nie as 'n statiese en bepalende mag gesien word wat die teks ad infinitum beheer nie en dat die kanon ook nie vas en onveranderlik is nie. Die outeur speel ' $n$ rol in die definiëring van die aard van die literatuur en die kanon word voortdurend opnuut bepaal deur die betrokke interpretatiewe gemeenskap. Ons het nie 'n kanon nodig om die ewige en onveranderlike groot tekste vas te stel nie, maar bloot as 'n instrument, 'n ooreenkoms op grond waarvan die interpretatiewe gemeenskap bepaalde tekste ter tafel neem en lees sodat 'n gesprek oor hierdie besondere tekste gevoer kan word. Dit impliseer dat enigeen wat 'n goeie leser is 'n teks kan voorlê en indien so 'n teks dan algemeen gelees word (leesbaar bevind word), kan daar 'n gesprek gevoer word. Ons moet op een of ander manier gemeenskaplike tekste op die tafel kry omdat daarsonder die

15. Ek brei hier uit op gedagtes wat deur Felperin (1985:200 e.v.) gesuggereer word. 
gesprek oor die literatuur moontlik kan vervlak tot blote kennisgewings van nuwe publikasies.

Dit is seker vir almal redelik maklik om te aanvaar dat die dosent die vóorleser is, wat geskool moet wees om so goed en interessant en kreatief as moontlik te lees en dat hy hierdie leeservaring met sy studente moet deel. Trouens dit is in groot mate die situasie in die departemente van Afrikaans aan die meeste universiteite. ${ }^{16}$

Dit is die aard van die geskooldheid waaroor verskil bestaan. Die vraag wat ek wil vra, is die volgende: kan ons op die lang duur bly werk met teorieë wat nie regtig veel gemeen het met die Afrikaanse literatuur en Suider-Afrikaanse literatuur nie? Lê die grootste uitdaging van die taak van literatore en teoretici nie daarin dat hulle 'n eie teoretiese tradisie moet ontwikkel of bevorder of tot stand bring nie? Moet ons die moeë nihilisme van Europa in ons lewenskragtige omstandighede soek? Kan ons die eeue-oue politieke griewe en sosiale vooroordele van Europa wat die literatuur perverteer tot instrument van mag, ongekwalifiseerd gebruik om die literêre toneel hier te beskryf?

Moet ons nie daarna strewe om 'n eie benadering te ontwikkel waarin sowel kreatiewe lees as kontekstuele verbondenheid 'n rol speel nie? Ons hoef tog nie van nuuts af te begin nie: 'n mens kan sekerlik voortbou op die teoretiese tradisies wat reeds bestaan. Trouens, ons mag selfs vind dat 'n teoretiese tradisie in Afrikaans reeds in embrio bestaan. Daar is die afgelope aantal jare baie en voortreflike studies gedoen wat die bestaande teorie reeds in 'n mate moes aanpas ter wille van 'n eie problematiek.

In die ontwikkeling van 'n selfstandige teoretiese tradisie sal daar baie navorsing gedoen moet word, waarin vergelykende studies sekerlik 'n groot rol sal speel. Miskien moet 'n mens opnuut gaan kyk hoe sien die hele korpus van literêre publikasies in Afrikaans daar uit, artistiek en teoreties. Om so 'n korpus te beskryf, sal terme en begrippe en konsepte aangepas en opnuut omskryf moet word. Gemeenskaplike eienskappe, tematies en stilisties, kan nagegaan en teoreties verantwoord word, maar daar sal veral aandag gegee moet word aan die verskeidenheid wat artistiek en teoreties onderskeibaar is. Ek staan nie hier 'n simplistiese empirisisme voor nie, ek noem net die moontlikheid dat dit dalk heilsaam vir die literatuur en die onderrig daarvan sou kon wees om van die filosofiese belastheid van ander tradisies te ontkom. Die kontemporêre Europese literêre teorie staan duidelik in die lyn van die ontwikkelinge wat die Europese toneel die afgelope twee eeue bepaal het, artistiek sowel as sosiopolities. En tog kan 'n mens die onderskeid tussen byvoorbeeld die Duitse en Franse benaderinge nie miskyk nie.

Literêre teorie kan nooit staties wees nie. Die werk wat reeds in Afrikaans oor Afrikaanse tekste gedoen is, kan as 'n vertrekpunt dien om sowel by wyse van radikale verskil as by wyse van organiese voortbou 'n nuwe tradisie te

16. Vergelyk E. Botha (1983) en Eco (1987). 
stimuleer. Miskien kan ons 'n wye, soepele raamwerk vind waarbinne die verskeidenheid van die Afrikaanse literatuur teoreties geakkommodeer kan word.

Die ideale situasie sou dan ook wees dat hierdie teoretiese navorsing kan deurwerk tot by Fakulteite van Opvoedkunde en Onderwysdepartemente sodat die kinders op skool reeds met 'n relevante en verantwoordbare kontemporêre siening van die literatuur en die gepaardgaande teoretiese benadering kan kennismaak. Vanselfsprekend word die ontwikkeling van 'n literêr-teoretiese tradisie as 'n dinamiese saak gesien wat voortdurend sal verander na gelang van ontwikkeling op verskillende terreine. Dit is egter noodsaaklik dat onderwysers kennis neem van die teoretiese dimensie van literatuuronderrig: dan sal hulle vinniger by verandering kan aanpas. ${ }^{17}$

Dit is natuurlik so dat eie teorievorming veel groter eise stel as die blote toepassing van bestaande teorie, want hierdie eie benadering sal wel ter wille van die internasionale gesprek in verband gebring moet word met die kontemporêre problematiek in die vakgebied by universiteite en instansies in ander lande. Dit lyk vir my in elk geval interessanter as om net al die klaarbedinkte gedagtes van ander oor en oor toe te pas.

Ek het myself aan die begin van die artikel getipeer as idealisties. Aangesien die literatuurteorie 'n mens filosofies bevange maak, wil ek dadelik byvoeg dat ek nie van idealisme praat in Hegeliaanse sin nie. Ek gebruik die woord idealisties gewoon en onpretensieus in die sin van "hopende op iets positiefs". Ek dink egter dat idealisme eie aan die literatuur is: die diepste depressie wat neergeskryf word, word neergeskryf in die idealistiese hoop dat dit, op welke wyse ook al, gelees sal word.

\section{Bibliografie}

Abrams, M.H. 1953. The mirror and the lamp. New York: Oxford University Press.

Barthes, R. 1974. S/Z. New York: Hill and Wang.

Belsey, C. 1980. Critical practice. London: Methuen.

Botha, Elize. 1983. Die dosent as leser. Pretoria: Universiteit van Suid-Afrika.

Culler, J. 1987. Poststructuralist criticism. Style: 21(2): Summer.

Culler, J. 1988. Framing the sign. Oxford: Basil Blackwell.

Degenaar, J. 1988. Intertekstualiteit. ALV Hoofkongres. Potchefstroom, ongepubliseerde referaat.

Derrida, J. 1976. Of grammatology. Vertaal deur G. Spivak. Baltimore: Johns Hopkins University Press.

Eagleton, T. 1983. Literary theory. Oxford: Basil Blackwell.

Eco, U. 1987. Interview. Diacritics: Spring.

Elsbree, L. 1982. The rituals of life. New York: Kennikat Press.

Felperin, H. 1985. Beyond deconstruction. Oxford: Clarendon Press.

Fokkema, D.W. \& Kunne-Ibsch, E. 1978. Theories of literature in the twentieth century. London: C. Hurst \& Company.

Hambidge, J. 1986. "Marilyn Monroe foto in blou": 'n dekonstruksie van die gedig as fototeks. In Senekal, J. red. Teks-Leser-Konteks. Johannesburg: Perskor.

17. Dit gaan hier om die teoretiese kennis van onderwysers en nie van leerlinge nie. 
Hutcheon, L. 1983. A poetics of postmodernism. Diacritics, 13(4): Winter.

Jameson, F. 1981. The political unconscious. New York: Cornell University Press.

Jefferson, A. \& Robey, D. 1982. Modern literary theory. London: Batsford Academic and Educational Ltd.

Johnson, B. 1980. The critical difference. Baltimore: Johns Hopkins University Press.

Klopper, D. 1985. Ideology and the study of South African English poetry. Tydskrif vir literatuurwetenskap: 3(4): Desember.

Levin, D.M. 1977. The novelhood of the novel: The limits of representation and the modernist discovery of presence. Chicago Review, 28(4).

Liebenberg, W. 1985. Deconstruction, literature and ideology. Tydskrif vir literatuurwetenskap, $1:(3)$ Julie.

Liebenberg, W. 1988. Die ideologie van Raka. ALV Hoofkongres. Potchefstroom, ongepubliseerde referaat.

Miller, J. Hillis. 1987. The ethics of reading. Style: 21(2): Summer.

Rumboll, F. 1985. Writing into Byron's Don Juan (Canto 9). The aporia of practice. Tydskrif vir literatuurwetenskap: 1(3): Julie.

Scholtz, M. 1985. Diskoers as self-ondermyning: J. Derrida/J. Miles. Tydskrif vir literatuurwetenskap: 1(3): Julie.

Viljoen, H. 1985. "Vakansiebrief" - 'n dekonstruksie-/dekonstruktiewe lesing. Tydskrif vir literatuurwetenskap: 1(4): Oktober. 